\title{
Vitamins $A$, and $C$ and folate status in Mexican children under 12 years and women 12-49 years: A probabilistic national survey
}

\author{
Salvador Villalpando, MD, PhD, ${ }^{(1)}$ Irene Montalvo-Velarde, Chem, ${ }^{(2)}$ N orma Zambrano, C hem, ${ }^{(1)}$ \\ Armando García-Guerra, MSc, ${ }^{(1)}$ Claudia Ivonne Ramírez-Silva, BSC, ${ }^{(1)}$ \\ Teresa Shamah-Levy, MSc, ${ }^{(1)}$ Juan A Rivera, MS, PhD. ${ }^{(1)}$
}

\section{Villalpando S, Montalvo-Velarde I, Zambrano N, García-Guerra A, Ramírez-Silva Cl, Shamah-LevyT, Rivera JA. Vitamins A, and C and folate status in Mexican children under 12 years and women 12-49 years: A probabilistic national survey. Salud Publica Mex 2003;45 suppl 4:S508-S519.} The English version of this paper is available too at: http://www.insp.mx/salud/index.html

\begin{abstract}
A bstract
Objective. To describe the epidemiology of Vitamin A and $\mathrm{C}$ and folic acid deficiencies and their association with socio demographic and dietary factors in a national probabilistic sample of Mexican women and children. Material and Methods This is a probabilistic sample from the $\mathrm{N}$ ational N utrition Survey 1999 (EN N -99) including 1966 children and 920 women.Vitamins $A$ and $C$ were measured in serum by high-performance liquid chromatography, and folic acid in total blood by a microbiological method. Determinants for such deficiencies were explored by multiple regression models. Results. Vitamin A deficiency (retinol $<10 \mu \mathrm{g} / \mathrm{dl}$ ) was rare in both children and women. But subclinical deficiency (retinol $>10$ and $<20 \mu \mathrm{g} / \mathrm{dl}$ ) was present in $25 \%$ of children. The likelihood of subclinical deficiency of vitamin $A$ was less in older children $(O R=0.98, p=0.01)$ and in women with higher body mass index ( $\mathrm{R}=0.93, \mathrm{p}=0.01$ ). A bo ut $30 \%$ of children $<2$ years of age and $40 \%$ of women were vitamin C deficient. The likelihood of vitamin C deficiency was less in children and women as socioeconomic level increased $(\mathrm{O}=0.69, p=0.03$, and $\mathrm{R}=0.80, p=0.04)$, and higher in older women $(O R=1.02, p=0.05)$. The prevalence of folate deficiency varied in children (2.3 to 11.2 ), in women it was $5 \%$. Folate deficiency was less in children of higher socioeconomic level $(O R=0.62, p=0.01)$, and in those eating more vegetables $(O R=0.22, p=0.01)$. Conclusions. The high prev-
\end{abstract}

\author{
Villalpando S, Montalvo-Velarde I, Zambrano N, \\ García-Guerra A, Ramírez-Silva CI, \\ Shamah-LeVyT, Rivera JA. \\ Estado de las vitaminas A y $C$, y folato en niños \\ menores de 12 años de edad y mujeres de entre \\ 12 a 49 años de edad. Una encuesta probabilística nacional. \\ Salud Publica Mex 2003;45 supl 4:S508-S519. \\ El texto completo en inglés de este artículo también \\ está disponible en: http://www.insp.mx/salud/index.html
}

\section{Resumen}

Objetivo. Describir la epidemiología de las deficiencias de las vitaminas A y C y del ácido fólico, y analizar su asociación con factores sociodemográficos y dietéticos en una muestra probabilística nacional de mujeres y niños mexicanos. Informar acerca del estado nutricio de estas vitaminas en una muestra probabilística nacional en México. Material y métodos Esta muestra pro babilística de la Encuesta $\mathrm{N}$ acional de N utrición 1999 incluyó 1966 niños y 920 mujeres. Las concentraciones séricas de las vitaminas A y C fueron medidas por cromatografía líquida de alta resolución H PLC (por sus siglas en inglés) y las de ácido fólico en sangre total por un método microbiológico. Se exploraron los posibles determinantes de la deficiencia de tales nutrimentos mediante modelos de regresión logística. Resultados. La deficiencia de vitamina A (retinol $<10 \mu \mathrm{g} / \mathrm{dl})$ fue rara, tanto en niños como en mujeres. El $25 \%$ de los niños de 1 a 8 años de edad tuvieron deficiencia subclínica (retinol $>10<20 \mu \mathrm{g} / \mathrm{dl}$ ). El riesgo de tener deficiencia subclínica de vitamina A fue menor en los niños de mayor edad $(0 R=0.98, p=0.01)$ y en mujeres con mayor índice de masa corporal $(0 R=0.93, p=0.01)$. El $30 \%$ de los niños $<2$ años de edad y $40 \%$ de las mujeres tuvieron deficiencia de vitamina C. El riesgo de esta deficiencia fue menor en niños y mujeres de nivel socioeconómico alto $(0 R=0.69, p=0.03, y$ $O R=0.80, p=0.04$ ), y mayor en mujeres de mayor edad

(1) Centro de Investigación en N utrición y Salud, Instituto N acional de Salud Pública. Cuernavaca, Morelos, México.

(2) Unidad de Investigación en N utrición, Centro Médico N acional Siglo XXI, Instituto Mexicano del Seguro Social, Ciudad de México, México.

Received on:August 20,2002 - Accepted on: 0 ctober 1,2003

Address reprint requests to: Dr. Salvador Villalpando. Instituto N acional de Salud Pública, Avenida U niversidad 655, colonia Santa María A huacatitlán 62508 Cuernavaca, Morelos, México. E-mail: svillalp@ insp.mx 
alence of subclinical deficiency of vitamin $A$ in children is indicative of risk of further deterioration under adverse circumstances. Vitamin $\mathrm{C}$ deficiency in both children and women implies in addition diminished ability for iron absorption. The English version of this paper is available too at: http://www.insp.mx/salud/index.html

Key words: vitamin A deficiency; vitamin C deficiency; folic acid deficiency; preschoolers; school-age children; women of childbearing age; M exico
$(0 R=1.02, p=0.05)$. En los niños la prevalencia de deficiencia de ácido fólico varió entre 2.3 y 11.2\%, en las mujeres de $5 \%$. El riesgo de tener deficiencia de folatos fue menor en niños con nivel socio económico alto ( $O R=0.66, p=0.04)$, y menor en aquellos que consumían más vegetales $(0 \mathrm{R}=$ $0.22, p=0.01$ ). Conclusiones. La alta prevalencia en México de deficiencia subclínica de vitamina $A$ en niños y de vitamina $C$ tanto en niños como en mujeres reclama acciones programáticas para reducirlas. El texto completo en inglés de este artículo también está disponible en: http:// ww w.insp. mx/salud/index.html

Palabras clave: deficiencia de vitamina A; deficiencia de vitamina C; deficiencia de ácido fólico; prescolares; escolares; mujeres en edad reproductiva; México
C hronic undernourishment is responsible for millions of deaths by increasing mortality rates. Those who do not die have a diminished ability to lead a secure and productive life because of morbidity and de-

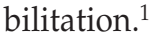

Endemic hunger, the energy and nutrient losses associated with high incidence of acute infections occurring perennially or as series of assaults, are included in the pathogenesis of chronic undernourishment. It is mainly manifested during childhood and adulthood as growth retardation and poor mental, physical and social performance. Micronutrient deficiencies are frequently involved as direct or indirect causal factors of malnutrition. It has been demonstrated that vitamin A and folate deficiencies have deleterious effects on the growth of animals ${ }^{2}$ and humans. ${ }^{3,4}$

Anemia can also be present when the nutritional status of folate, vitamins B12 and A is inadequate..$^{5,6}$ In addition to the classic manifestations of overt vitamin deficiencies, other pathologies have recently been discovered to be associated with mild vitamin deficiencies. Folate deficiency is related to congenital defects in the closure of the neural tube, ${ }^{7}$ vitamin A deficiency increases the mortality risk associated with diarrhea and measles, ${ }^{2}$ and vitamin C deficiency has been implicated with premature membrane rupture during pregnancy as well as with prematurity. 8,9 Many of these vitamins play a crucial role in preventing chronic diseases in adult life because of their antioxidant capacity. ${ }^{10}$

Good epidemiological data about the prevalence of stunting in Mexico is available ${ }^{11,12}$ and the newest has been published recently. ${ }^{13}$ The nutritional status of micronutrients in Mexican populations is contained in just a few studies, frequently not representative country- or region-wide. ${ }^{14,15}$ Comprehensive information about microminerals is published elsewhere within this issue. Information about the prevalence of micronu- trient deficiencies is of prime importance for the design and implementation of public health nutrition programs in a country such as Mexico, in need of efficacious interventions to correct nutrition deficiencies that interfere with the potential development of human resources.

This investigation aims to describe the prevalence and distribution of deficiencies of vitamins $A$ and $C$, and folate, based on determinations in blood of such micronutrients obtained from a probabilistic sample of Mexican children $<12$ years of age and of women 12 to 49 years of age.

\section{Material and Methods}

Data were extracted from the database of the National Nutrition Survey, carried out in 1999 (ENN-99). The methodology of this probabilistic survey was published in detail elsewhere. ${ }^{13}$ Briefly, the sampling procedure included a randomized selection of households based on the master household frame provided by Instituto Nacional de Estadística, Geografía e Informática (INEGI). Blood samples were obtained in subsamples of preschool children $(<5$ years of age) and school-age children (6 to 11 years of age) and women of child-bearing age (12-49) constituting $6.6 \%$ of the 21000 households originally selected.

After prevalence was calculated, an expansion factor was applied to represent the original population. The expansion factors were calculated based on the characteristics of the Mexican population in 1995 from census data published by Instituto Nacional de Estadística Geografía e Informática.

For the present analysis, data from children of both sexes $<12$ years of age and women aged 12-49 years were used, including information about their serum concentrations of retinol (vitamin A), ascorbic acid (vi- 
tamin C) in serum, and folate in total blood. In addition, the following sociodemographic information was analyzed: birth date, gender, maternal education, socioeconomic level, ethnic origin, consumption of dietary supplements, being recipients of any food assistance program, and dietary intake. Maternal education was stratified into the following categories based on completed education cycles: no schooling, primary school (6 years), secondary school (9 years) and high school or higher ( $>12$ years).

Socioeconomic level was continuous variable, using a scale based on a principal component analysis of household possessions and characteristics. Ethnic origin was categorized as indigenous for subjects belonging to families in which at least one woman 12-49 years spoke a native language. Dietary supplements included vitamin and/or mineral preparation, or enriched food provided within a formal public nutrition intervention. Food assistance was considered as present when the family or the study subject was a beneficiary of any program providing food "in kind" or at subsidized prices.

Chronological age of children was divided into 1year intervals. Women were categorized as pregnant or nonpregnant, relying on self-reports. Subjects were categorized as rural if they lived in a community of $<2,500$ inhabitants; all others were categorized as urban. The country was divided arbitrarily into four geographic regions: the North region included the states of Baja California, Baja California Sur, Coahuila, Chihuahua, Durango, Nuevo León, Sonora and Tamaulipas. The Center included the states of Aguascalientes, Colima, Guanajuato, Jalisco, México, Michoacán, Morelos, Nayarit, Querétaro, San Luis Potosí, Sinaloa and Zacatecas. The metropolitan region of Mexico City included the Federal District but not nearby urban areas. The South region included the states of Campeche, Chiapas, Guerrero, Hidalgo, Oaxaca, Puebla, Quintana Roo, Tabasco, Tlaxcala, Veracruz and Yucatán.

\section{Blood sample collection, preparation and preservation}

Blood samples were drawn from a vein in the forearm, in glass tubes specially prepared for microminerals (Vacutainer, purple cap tubes, Beckton Dickinson, Inc., Franklin Lakes, NJ, USA). Serum was immediately separated within the household premises using a portable centrifuge EBA8 (Hettich, Tuttlingen, Germany) and transferred into several color-coded cryovials, according to the vitamins to be determined, and preserved in liquid nitrogen protected from light until delivery to a central laboratory. Samples intended for ascorbic acid determination were combined with 0.1 $\mathrm{ml}$ of $0.1 \mathrm{M}$ metaphosphoric acid before freezing. Also, whole blood samples for folate determinations were collected on filter paper. Blood samples were collected from November 1998 to March 1999, which in Mexico is a single season (winter).

Methods for micronutrient determinations. Retinol (vita$\min \mathrm{A}$ ), and ascorbic acid (vitamin C) were determined in serum samples. Folate was determined in total blood after elution from embedded filter paper.

Vitamin A (retinol). Serum retinol was extracted with $100 \%$ pure ethanol; the ethanol was evaporated under a nitrogen flux and redissolved in $100 \mathrm{ml}$ of $10 \%$ ethanol. Determinations were performed by high-performance liquid chromatography (HPLC) ${ }^{16}$ in a Waters instrument (Waters Co., Milford, MA, USA), using a $3.9 \times 150$ mm column Nova-Pak C18 ODS (Waters Co.), with a mobile phase of $\mathrm{CH}_{3} \mathrm{OH}, 100 \%$ with a flux velocity of $1.5 \mathrm{ml} / \mathrm{min}$, at a wavelength of $325 \mathrm{~nm}$. Overall interassay variation coefficient was $6.6 \%$, intraassay variation coefficient ranged 2.0 to $2.4 \%$ when determining a QC serum certified to have a concentration of $24.1 \mu \mathrm{g} / \mathrm{dl}$ of retinol. Certified NIST 968C-SRM human serum level I (81.4-86.8 $\mu \mathrm{g} / \mathrm{dl})$ gave a measurement in our laboratory of $86.7 \pm 1.7$, and serum level II $(47.2-49.6 \mu \mathrm{g} / \mathrm{dl})$ was $50.0 \pm 1.3$.

Cut-off values of retinol used to classify vitamin A status were those of the International vitamin A Consultative Group (IVACG) and used in NHANES of the USA: normal, $>20 \mu \mathrm{g} / \mathrm{dl}$; subclinical deficiency, 10-20 $\mu \mathrm{g} / \mathrm{dl} ;$ and deficiency, $<10 \mu \mathrm{g} / \mathrm{dl} .{ }^{17}$

Folate. Hemoglobin Folate (HF) values were measured using dried blood spots on filter paper by the method described and validated by $\mathrm{O}^{\prime}$ Broin et al ${ }^{18-20}$ In short, blood spots were collected on filter paper sheet No. 903 (S\&S, Inc., New York, NY, USA). Filter paper sheets were allowed to dry in a light-protected environment. Once the sheets were completely dry, they were wrapped in absorbent paper and stored in zippered plastic bags, containing two desiccant sachets, at $4^{\circ} \mathrm{C}$ until storage in the central lab at $-20^{\circ} \mathrm{C}$. Dried spots were extracted by sonication in phosphate/ascorbic acid buffer. Eluates were assayed for folate in whole blood by a microbiological method using Lactobacillus caseii as the sensitive organism ${ }^{21}$ and for $\mathrm{Hb}$ content by a colorimetric method. HF values were calculated by dividing the whole blood-folate concentration by the sample hemoglobin concentration and then multiplied by blood hemoglobiin concentrations. ${ }^{18}$ In a validation procedure carried out by the authors of the method, HF values correlated well with the erythrocyte folate concentrations of normal Americans mea- 
sured by conventional methods $\left(r^{2}=0.99 ; n=11887\right) .{ }^{18}$ Equivalence between true measurements of folate in erythrocytes and HF was assessed in our laboratory by regressing values measured simultaneously in the same sample of Mexican women (unpublished data). The resulting equation was:

Hemoglobin folate $=-1.31+0.415$ Folate in erythrocytes

Overall interassay variation coefficient was $11.6 \%$, when determining a QC serum certified to have a concentration of $25.0 \mu \mathrm{g} / \mathrm{dl}$ of folate. Certified NIST 1846 infant formula $(80.0 \mu \mathrm{g} / \mathrm{dl})$ gave a measurement in our laboratory of $81.8 \pm 9.5 \mu \mathrm{g} / \mathrm{dl}$

We used the cut-off values for folate in erythrocytes published in the guidelines for the interpretation of folate concentrations ${ }^{22}$ and they are as follow: normal: $>160 \mu \mathrm{g} / \mathrm{dl}$, depletion 140-160 $\mu \mathrm{g} / \mathrm{dl}$, deficiency: <140 $\mu \mathrm{g} / \mathrm{dl}$.

Vitamin C . Vitamin C (ascorbic acid) was determined in the supernatant of serum precipitated with metaphosphoric acid, then spun down at $1000 \mathrm{~g}$ for $15 \mathrm{~min}^{23}$ Supernatant was injected without further purification directly into the HPLC instrument (Waters Co.). The HPLC was equipped with a Decade electrochemical sensor (Antec Leyden, Leyden, Deutchland). Overall interassay variation coefficient was $3.7 \%$, intraassay variation coefficient ranged 1.8 to $2.1 \%$ when determining a QC serum certified to have a concentration of $0.45 \mathrm{mg} / \mathrm{dl}$ of ascorbic acid. Certified NIST 1846 infant formula $(0.22 \mathrm{mg} / \mathrm{dl})$ gave a measurement in our laboratory of $0.205 \pm 0.004 \mu \mathrm{g} / \mathrm{dl}$.

Cut-off values of ascorbic acid concentrations were defined as indicative of normality, $>0.3 \mathrm{mg} / \mathrm{dl}$; moderate risk for deficiency, $0.3-0.2 \mathrm{mg} / \mathrm{dl}$; and high risk for deficiency, $<0.2 \mathrm{mg} / \mathrm{dl}$, as recommended by Sauberlich. ${ }^{24}$

Assessment of dietary intake. The micronutrient intake of children was assessed by 24-h recall applied to the mother. The dietary intake of women aged 12-48 years was assessed by the same method applying the questionnaire directly to the subjects. The nutrient value of foods was calculated by multiplying the portion size in grams of a given food by the nutrient content per gram of that food. Food composition data were obtained by combining micronutrient information from seven published food composition tables ${ }^{25-30}$ and from the unpublished composition table: Información $\mathrm{Nu}$ tricional de Marinela (Marinela Company, México D.F). The pooling process was performed at Instituto Nacional de Salud Pública, Cuernavaca, Morelos, Mexico.
Data analysis. Description of variables was made by central tendency and dispersion statistics. The prevalence of each micronutrient is presented as rates and confidence intervals. Actual sample size for any category presented here was expanded after prevalences were calculated using a population factor.

Also, logistic regression models which controlled for the clustered design of the study were constructed in order to identify potential predictors of the nutritional status for each vitamin. Status for individual vitamins were coded as normal or abnormal according to the following cut-off values: retinol $<20 \mathrm{ug} / \mathrm{dl}$, vitamin $\mathrm{C}<0.2 \mathrm{mg} / \mathrm{dl}$ and folate $<65 \mathrm{ug} / \mathrm{dl}$ ), and introduced into the models as dependent variable. Age, gender, socioeconomic level, ethnic status, participating in food assistance programs, and the daily intake of the following food groups: cereals, animal food, legumes, and vegetables, were introduced as independent variables. Food intake was expressed as 100 gram portions per day. Food assistance programs included in the questionnaire were Fidelist and Liconsa, distributors of tortillas and milk at subsidized prices, and DIF, distributor of free food baskets. PROGRESA was not included because at the time of the survey distribution of fortified food was just starting. Because of the great co-linearity between socioeconomic level, maternal education and height we choose to introduce socioeconomic level into the model, and not maternal education, height or height/age. There is difficulty in explaining the association of nutritional status of micronutrients and dietary variables, because the latter are associated with socioeconomic level (SEL). Controlling for SEL when examining associations with diet may represent overcontrolling. Thus, to avoid it we constructed two additional restricted models in which only socioeconomic variables or dietary variables were alternately introduced as independent variables.

Data analysis was performed using statistal analysis software (Stata 7.0 for Windows v. 7, College Station, Texas, USA, 2000; SPSS for Windows, v 10.0, Chicago, USA, 1999).

\section{Results}

Data for 1966 children and 920 women were obtained; however, the sample size varies for each nutrient because of sample losses or erroneous results. Description of the sample is summarized in Table I. The global response rate of ENN-99 was $92 \%$. The subsample obtained for serum micronutrient determinations represents approximately $10 \%$ of the global sample for ENN-99; it has the statistical power to be representa- 
Table I

\section{SOME DESCRIPTIVE DATA ON THE SAMPLE OF CHILDREN UNDER 12 AND WOMEN 12-49 YEARS OF AGE WITH AVAILABLE DETERMINATIONS OF SERUM VITAMINS $A, C$ AND FOLATE. National Nutrition Survey, Mexico, 1999}

\begin{tabular}{lrrr} 
& Sample & \multicolumn{2}{c}{$\begin{array}{c}\text { Expanded } \\
\text { (thousands) }\end{array}$} \\
\cline { 3 - 4 } Characteristics & $n$ & $n$ & $\%$ \\
$\begin{array}{l}\text { Women 12- } 49 \text { years of age } \\
\text { BMI (kg/height }{ }^{2} \text { ) } \\
<18.5\end{array}$ & & & \\
\hline 18.5 a 24.9 & 18 & 119.2 & 1.3 \\
\hline 25 a 29.9 & 392 & 3935.7 & 43.4 \\
\hline$\geq 30$ & 278 & 3157.7 & 34.8 \\
\hline & 203 & 1858.4 & 20.5
\end{tabular}

\begin{tabular}{llll}
$\begin{array}{l}\text { SEL* } \\
\text { Low }\end{array}$ & 305 & 2747.3 & 29.5 \\
\hline Medium & 310 & 2937.7 & 31.5 \\
\hline High & 305 & 3639.0 & 39.0
\end{tabular}

\begin{tabular}{crrr}
$\begin{array}{c}\text { Residence } \\
\text { Urban }\end{array}$ & 581 & 6956.1 & $74.6 \%$ \\
\hline Rural & 339 & 2368.0 & $25.4 \%$ \\
\hline Age (years) & 920 & 9324.1 & $29.2 \pm 9.4^{\ddagger}$
\end{tabular}

Children $<12$ years of age

Gender

\begin{tabular}{crrr} 
Male & 1011 & 12093.4 & 52.1 \\
\hline $\begin{array}{c}\text { Female } \\
\text { Age group }\end{array}$ & 955 & 11125.3 & 47.9 \\
$0-2$ & 107 & 2380.2 & 10.3 \\
$3-4$ & 298 & 7215.3 & 31.1 \\
\hline $5-6$ & 375 & 3081.2 & 13.3 \\
\hline $7-8$ & 472 & 4008.9 & 17.3 \\
\hline $9-10$ & 492 & 4699.5 & 20.2 \\
\hline 11 & 222 & 1833.6 & 7.9
\end{tabular}

\begin{tabular}{crrr}
$\begin{array}{c}\text { Residence } \\
\text { Rural }\end{array}$ & 895 & 7207.4 & 31.0 \\
\hline Urban & 1071 & 16011.3 & 69.0
\end{tabular}

\begin{tabular}{lrrr}
\multicolumn{2}{l}{ SEL } \\
Low & 763 & 8908.2 & 38.4 \\
\hline Medium & 490 & 5897.7 & 25.4 \\
\hline High & 713 & 8412.7 & 36.2 \\
\hline Total & 1966 & 23218.7 &
\end{tabular}

* Socioeconomic status was categorized into three levels, by a construct based on principal component analysis of household possessions and characteristics

₹ Mean \pm tive at the national level and for urban and rural strata (see the methodology article in this issue). Although we present data related to geographic regions and to certain age intervals, they must be interpreted with caution because of limited sample size.

\section{Children under 12 years of age}

Vitamin A (retinol) status. The prevalence of vitamin A deficiency in children was very low. It was mostly seen in rural children $<2$ years. Slightly more than $25 \%$ of the children $<8$ years of age had subclinical vitamin A deficiency; this prevalence declined abruptly by $50 \%$ from 9 years of age and up. There was no significant difference between rural and urban children (Tables I and II). The highest prevalence of mild vitamin A deficiency occurred in the North $(22.5 \%)$ and center $(26.5 \%)$ regions, and the lowest occurred in the Mexico City region.

The likelihood of having subclinical deficiency of vitamin A was less in the older children $(\mathrm{OR}=0.98$, $p=0.01$ ). No effect of indigenous ethnicity, being beneficiary of food assistance programmes or the intakes of cereal, meat or legumes was noted (Table III).

Vitamin C (ascorbic acid) status. About one third of infants $<2$ years of age had serum concentrations of vitamin $C$ indicative of high risk of deficiency. This prevalence lessened progressively, but it reappeared at 11 years of age in both rural and urban children. The summed prevalence of moderate and high risk for deficiency of vitamin C yielded an overall prevalence above $25 \%$ (Tables II and IV). The North and South regions had the highest combined prevalence of high and moderate vitamin C deficiency (26.8 and 25.8\%, respectively) while the lowest was found in the Mexico City region $(12.2 \%)$.

The likelihood of having vitamin $C$ deficiency was less in the children as socioeconomic status increased $(\mathrm{OR}=0.69, p=0.03)$. Age, ethnicity, being a beneficiary of food assistance programmes or the intakes of any food group were not significantly associated (Table III). Folate status. The prevalence of folate concentrations in total blood compatible with severe deficiency was higher in both urban and rural children $<4$ years of age compared to other age groups. The prevalence varied between 2.8 and $13 \%$. In older children the prevalence of severe folate deficiency varied from 2.3 to $6.3 \%$ with no significant difference between rural and urban. The sum of prevalences of mild and severe folate deficiency did not exceed $15 \%$ in any age group at the national level (Tables II and IV). The North and South regions had the highest prevalence of severe folate deficiency (14.3 and 8.5\%, respectively). The lowest 


\section{Prevalence of vitamins A and C, and folate deficiencies in Mexican children under 12 years of age. National Nutrition Survey, Mexico, 1999}

\begin{tabular}{|c|c|c|c|c|c|c|c|}
\hline \multirow[b]{2}{*}{ Vitamin A } & \multirow{2}{*}{$\begin{array}{l}\text { Age group } \\
\text { (years) }\end{array}$} & \multirow{2}{*}{$\begin{array}{c}\text { Sample } \\
n\end{array}$} & \multirow{2}{*}{$\begin{array}{l}\text { Expanded (thousands) } \\
\text { N }\end{array}$} & \multicolumn{2}{|c|}{ Prevalence } & \multicolumn{2}{|c|}{$\begin{array}{c}\text { Serum or total } \\
\text { blood concentrations* }\end{array}$} \\
\hline & & & & $\%$ & $95 \% \mathrm{Cl}$ & Mean & $95 \% \mathrm{Cl}$ \\
\hline \multicolumn{8}{|c|}{ Children } \\
\hline (retinol, & $0-2$ & 79 & 1889.3 & 27.9 & $\ddagger$ & 23.0 & $(22.4,23.7)$ \\
\hline sub-clinical deficiency & $3-4$ & 243 & 6229.1 & 26.4 & $(21.67,31.07)$ & 23.4 & $(22.6,24.2)$ \\
\hline \multirow[t]{5}{*}{$\geq 10,<20 \mathrm{mg} / \mathrm{dl})$} & $5-6$ & 329 & 2664.7 & 25.7 & $(21.62,29.68)$ & 23.5 & $(23.1,23.9)$ \\
\hline & $7-8$ & 420 & 3623.4 & 25.1 & $(21.27,28.98)$ & 24.3 & $(23.8,24.8)$ \\
\hline & $9-10$ & 439 & 4242.7 & 12.5 & $(8.95,16.05)$ & 25.7 & $(25.1,26.2)$ \\
\hline & 11 & 199 & 1642.3 & 9.7 & $(5.92,13.39)$ & 26.9 & $(25.8,28.1)$ \\
\hline & Total & 1709 & 20291.5 & 21.9 & $(20.00,23.89)$ & 24.3 & $(24.01,24.60)$ \\
\hline $\begin{array}{l}\text { Vitamin C } \\
\text { (ascorbic acid, } \\
\text { deficiency }\end{array}$ & $\begin{array}{l}\text { Non-pregnant women } 12-49 \text { years } \\
\text { Children age (years) }\end{array}$ & 855 & 8684 & 4.3 & $\neq$ & 36.3 & $(35.8,36.8)$ \\
\hline \multirow[t]{7}{*}{$\leq 0.2 \mathrm{mg} / \mathrm{dl})$} & $0-2$ & 85 & 1947.4 & 30.3 & $\neq$ & 0.4 & $(0.37,0.46)$ \\
\hline & 3-4 & 261 & 6569.2 & 24.2 & $(19.38,29.10)$ & 0.5 & $(0.44,0.50)$ \\
\hline & $5-6$ & 351 & 2935.3 & 17.3 & $(13.66,20.93)$ & 0.6 & $(0.55,0.63)$ \\
\hline & $7-8$ & 438 & 3743.2 & 21.5 & $(18.28,24.81)$ & 0.5 & $(0.50,0.56)$ \\
\hline & 9-10 & 471 & 4566.4 & 19.8 & $(16.24,23.44)$ & 0.5 & $(0.49,0.55)$ \\
\hline & 11 & 209 & 1717.1 & 31.1 & $(24.07,38.04)$ & 0.5 & $(0.41,0.51)$ \\
\hline & Total & 1815 & 21478 & 23.0 & $(20.65,25.32)$ & 0.5 & $(0.48,0.52)$ \\
\hline $\begin{array}{l}\text { Folate } \\
\text { (deficiency }\end{array}$ & N on-pregnant women $12-49$ years & 888 & 8921 & 39.3 & $(36.4,42.1)$ & 0.34 & $(0.32,0.35)$ \\
\hline \multirow[t]{9}{*}{$\leq 57 \mathrm{ng} / \mathrm{ml})$} & Children age (years) & & & & & & \\
\hline & $0-2$ & 69 & 1344.2 & 8.8 & $\neq$ & 131.6 & $(118.1,145.1)$ \\
\hline & 3-4 & 191 & 4227.5 & 11.2 & $\neq$ & 145.1 & $(98.4,191.7)$ \\
\hline & $5-6$ & 246 & 2012.9 & 4.6 & $\ddagger$ & 131.5 & $(122.4,140.7)$ \\
\hline & $7-8$ & 326 & 2690.2 & 6.4 & 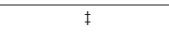 & 142.4 & $(128.4,156.4)$ \\
\hline & 9-10 & 334 & 2652.7 & 5.3 & 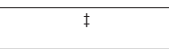 & 133.0 & $(124.9,141.2)$ \\
\hline & 11 & 139 & 1172.4 & 2.3 & $\ddagger$ & 140.1 & $(129.2,151.0)$ \\
\hline & Total & 1305 & $14,100.0$ & 7.3 & $(6.07,8.45)$ & 138.7 & $(123.7,151.0)$ \\
\hline & N on-pregnant women $12-49$ years & 603 & 5874 & 5.0 & $(3.6,6.4)$ & 134.7 & $(130.0,139.4)$ \\
\hline \multicolumn{8}{|c|}{$\begin{array}{l}\text { * Retinol and ascorbic acid in serum, folic acid in total blood } \\
\neq \text { Insufficient sample size for calculations } \\
\text { a } n=\text { number of cases in the sample } N=\text { number of cases after }\end{array}$} \\
\hline
\end{tabular}

prevalence was seen in the Center and Mexico City regions.

The likelihood of having folate deficiency was less in the higher SEL $(\mathrm{OR}=0.62, p=0.01)$, and in those eating more vegetables $(\mathrm{OR}=0.22, p=0.01)$. No association was noted with other socioeconomic or dietary variables introduced into the model (Table III).

\section{Women 12-49 years of age}

Vitamin A (retinol) status. The prevalence of retinol levels indicative of severe deficiency was marginal $(0.4 \%)$, and found only in the center. The prevalence of vitamin A depletion (serum concentrations of retinol $<10$ and $>20 \mathrm{mg} / \mathrm{dl}$ ) was also low $(4.3 \%)$, with no differ- 


\section{Table III \\ Logistic regression models of Vitamin A, Vitamin C and folate on potentially predictive variables on Children $<12$ years of age. National Nutrition Survey, Mexico, 1999}

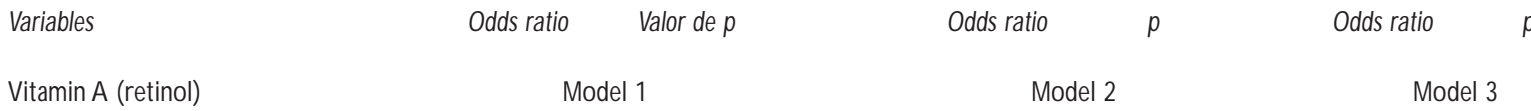

$n=438$

\begin{tabular}{|c|c|c|c|c|c|c|}
\hline Age (months) & 0.983 & 0.01 & 0.981 & 0.01 & & \\
\hline$\overline{\text { SEL* }}$ & 1.342 & 0.35 & 1.307 & 0.40 & & \\
\hline$\overline{B F A P \ddagger}$ & 1.668 & 0.17 & 1.688 & 0.17 & & \\
\hline Indigenous $s^{\S}$ & 2.131 & 0.29 & 2.624 & 0.12 & & \\
\hline Cereals $(100 \mathrm{~g} / \mathrm{d})$ & 0.888 & 0.44 & & & 0.741 & 0.11 \\
\hline Meat $(100 \mathrm{~g} / \mathrm{d})$ & 0.603 & 0.30 & & & 0.525 & 0.16 \\
\hline Leguminous (100g/d) & 0.802 & 0.38 & & & 0.782 & 0.33 \\
\hline$\overline{\text { Vegetables }(100 \mathrm{~g} / \mathrm{d})}$ & 1.004 & 0.96 & & & 0.961 & 0.72 \\
\hline
\end{tabular}

Vitamin C (ascorbic acid) Model 1

Model 2

Model 3

$n=458$

\begin{tabular}{|c|c|c|c|c|c|c|}
\hline Age (months) & 1.007 & 0.12 & 1.007 & 0.09 & & \\
\hline$\overline{\mathrm{SEL}}$ & 0.727 & 0.07 & 0.698 & 0.03 & & \\
\hline$\overline{B F A P}$ & 1.087 & 0.79 & 1.121 & 0.72 & & \\
\hline Indigenous & 0.923 & 0.89 & 0.990 & 0.98 & & \\
\hline Cereals $(100 \mathrm{~g} / \mathrm{d})$ & 1.064 & 0.55 & & & 1.171 & 0.11 \\
\hline$\overline{\text { Meat }(100 \mathrm{~g} / \mathrm{d})}$ & 0.682 & 0.13 & & & 0.654 & 0.12 \\
\hline Leguminous (100g/d) & 0.707 & 0.17 & & & 0.724 & 0.21 \\
\hline Vegetable $(100 \mathrm{~g} / \mathrm{d})$ & 1.109 & 0.32 & & & 1.111 & 0.30 \\
\hline Folate & \multicolumn{2}{|c|}{ Model 1} & \multicolumn{2}{|c|}{ Model 2} & \multicolumn{2}{|c|}{ Model 3} \\
\hline \multicolumn{7}{|l|}{$n=342$} \\
\hline Age (months) & 1.001 & 0.84 & 0.997 & 0.70 & & \\
\hline$\overline{S E L}$ & 0.668 & 0.04 & 0.621 & 0.01 & & \\
\hline BFAP & 1.424 & 0.47 & 1.388 & 0.49 & & \\
\hline Indigenous & 0.702 & 0.57 & 1.439 & 0.59 & & \\
\hline Cereals $(100 \mathrm{~g} / \mathrm{d})$ & 0.954 & 0.74 & & & 1.008 & 0.95 \\
\hline Meat $(100 \mathrm{~g} / \mathrm{d})$ & 0.767 & 0.39 & & & 0.686 & 0.24 \\
\hline Leguminous $(100 \mathrm{~g} / \mathrm{d})$ & 0.715 & 0.51 & & & 0.744 & 0.53 \\
\hline Vegetables $(100 \mathrm{~g} / \mathrm{d})$ & 0.266 & 0.01 & & & 0.223 & 0.01 \\
\hline
\end{tabular}

* Socioeconomic status was a continuous variable by a construct based on principal component analysis of household possessions and characteristics

₹ BFAP (Beneficiary of food assistance programmes, was a dummy variable; $1=$ yes and $0=$ no) belongs to a family receiving corn tortillas or milk at subsidized prices, or free food baskets

$\S$ Indigenous was a dummy variable $(1=$ yes and $0=$ no $)$

ences between rural and urban women and among regions (Tables II and IV).

The likelihood of having subclinical deficiency of vitamin A was lower in women with higher BMI $(\mathrm{OR}=0.93, p=0.01)$. No association with age, SEL, being beneficiary of food assistance programmes, ethnicity or the intakes of any food group in particular was noted (Table V).

Vitamin C (ascorbic acid) status. The prevalence of serum vitamin $C$ levels indicative of high risk for defi- ciency was near $40 \%$ nationwide with no differences between rural and urban women. The highest prevalence was observed in the North and South regions. Milder deficiencies were less prevalent, i.e., $11 \%$ across groups (Tables II and IV).

The likelihood of having vitamin $\mathrm{C}$ deficiency was higher in women (OR=1.02, $p=0.05)$, and lower in those of higher SEL (OR=0.80, $p=0.04$ ). No significant association occurred with other social and dietary data introduced into the model (Table V). 


\section{Table IV}

\section{Prevalence of Vitamins A and C, and folate deficiencies in Children 412 years of age, rural and urban residence. National Nutrition Survey, Mexico, 1999}

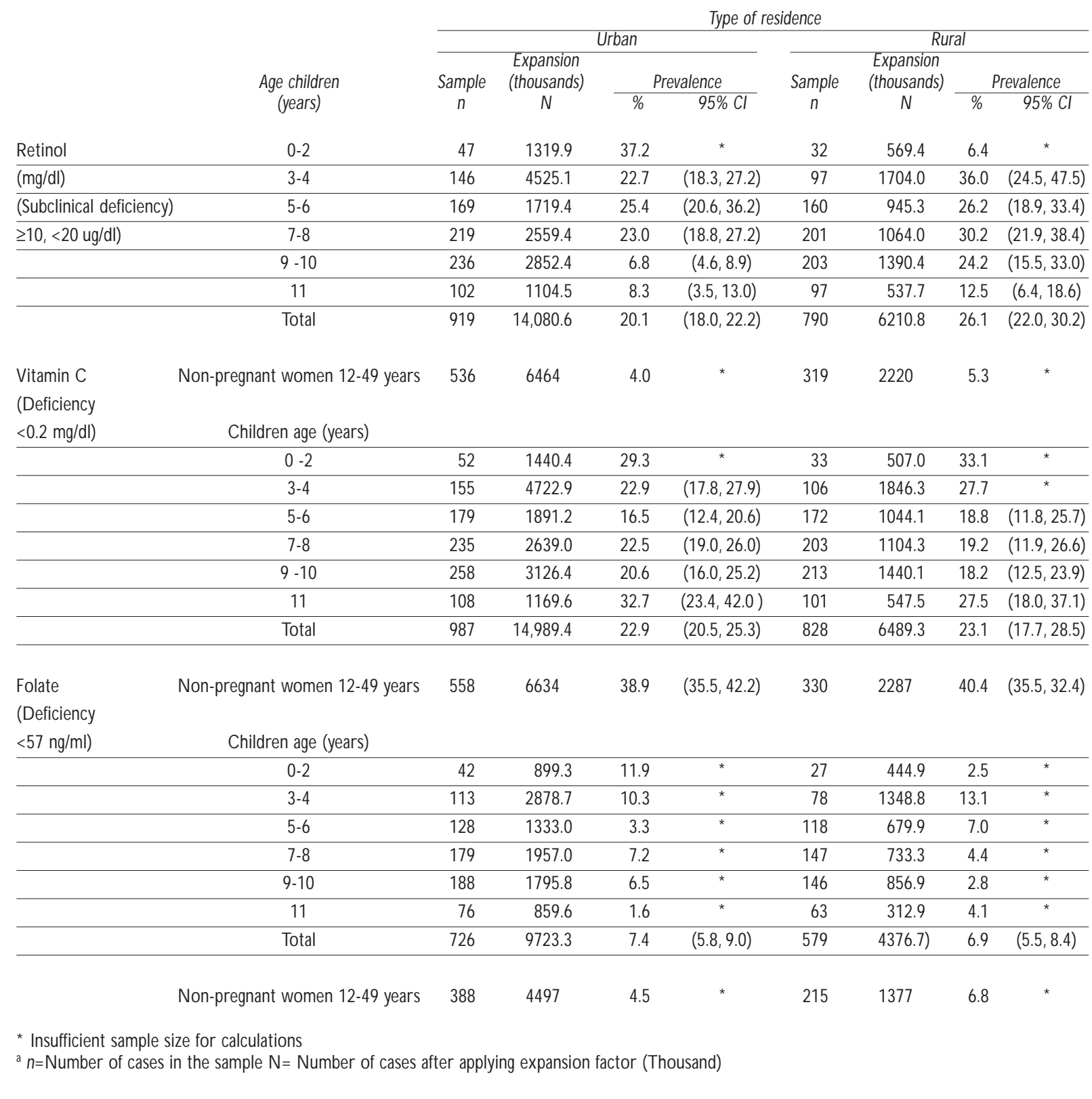

Folate status. Overt hemoglobin folate deficiency was approximately $5 \%$ at the national level with no significant difference between urban and rural women (4.5 and $6.8 \%$, respectively). Overt folate deficiency was more prevalent in the North and South regions than in the Center and Mexico City regions.

The likelihood of having folate deficiency was not associated with either socioeconomic or dietary variables included in the model.

\section{Discussion}

We present evidence here that the prevalence of vitamin A and folate deficiencies are of moderate concern from a public health standpoint in Mexico, while the vitamin $C$ deficiency had an unexpectedly high prevalence in both children and women.

Although the prevalence of severe vitamin A deficiency $(<10 \mathrm{mg} / \mathrm{dl})$ was practically nonexistent in 
Table V

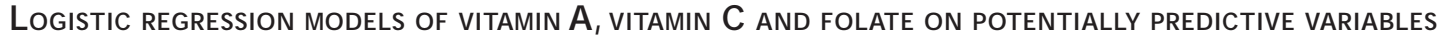 on non-pregnant women 12-49 years of age. National Nutrition SurVey, MeXico, 1999}

\begin{tabular}{|c|c|c|c|c|c|c|}
\hline \multirow{2}{*}{$\begin{array}{l}\text { Variables } \\
\text { Vitamin A (retinol) }\end{array}$} & \multicolumn{2}{|c|}{ Model 1} & \multicolumn{2}{|c|}{ Model 2} & \multicolumn{2}{|c|}{ Model 3} \\
\hline & odds ratio & $p$ & Odds ratio & $p$ & Odds ratio & $p$ \\
\hline \multicolumn{7}{|l|}{$n=837$} \\
\hline Age (months) & 1.007 & 0.69 & 1.007 & 0.68 & & \\
\hline Body Mass Index & 0.935 & 0.01 & 0.939 & 0.01 & & \\
\hline$\overline{\text { SEL* }}$ & 1.222 & 0.33 & 1.221 & 0.31 & & \\
\hline$\overline{\text { BFAP } \ddagger}$ & 1.350 & 0.45 & 1.373 & 0.40 & & \\
\hline Indigenous ${ }^{\S}$ & 0.488 & 0.43 & 0.438 & 0.36 & & \\
\hline Cereals $(100 \mathrm{~g} / \mathrm{d})$ & 0.932 & 0.49 & & & 0.920 & 0.42 \\
\hline Meat $(100 \mathrm{~g} / \mathrm{d})$ & 1.102 & 0.57 & & & 1.112 & 0.50 \\
\hline Leguminous (100g/d) & 1.122 & 0.65 & & & 1.034 & 0.90 \\
\hline Vegetables $(100 \mathrm{~g} / \mathrm{d})$ & 0.715 & 0.49 & & & 0.748 & 0.51 \\
\hline Vitamin C (ascorbic Acid) & \multicolumn{2}{|c|}{ Model 1} & \multicolumn{2}{|c|}{ Model 2} & \multicolumn{2}{|c|}{ Model 3} \\
\hline \multicolumn{7}{|l|}{$n=807$} \\
\hline Age (months) & 1.019 & 0.07 & 1.020 & 0.05 & & \\
\hline Body Mass Index & 1.005 & 0.72 & 1.007 & 0.63 & & \\
\hline$\overline{\text { SEL }}$ & 0.827 & 0.09 & 0.805 & 0.04 & & \\
\hline BFAP & 1.174 & 0.50 & 1.194 & 0.45 & & \\
\hline Indigenous & 1.013 & 0.96 & 0.962 & 0.90 & & \\
\hline Cereals (100g/d) & 0.976 & 0.68 & & & 0.993 & 0.907 \\
\hline Meat $(100 \mathrm{~g} / \mathrm{d})$ & 0.994 & 0.95 & & & 0.992 & 0.724 \\
\hline Leguminous (100g/d) & 0.987 & 0.93 & & & 1.024 & 0.873 \\
\hline Vegetables $(100 \mathrm{~g} / \mathrm{d})$ & 0.883 & 0.21 & & & 0.854 & 0.120 \\
\hline Folate & \multicolumn{2}{|c|}{ Model 1} & \multicolumn{2}{|c|}{ Model 2} & \multicolumn{2}{|c|}{ Model 3} \\
\hline \multicolumn{7}{|l|}{$n=591$} \\
\hline Age (months) & 0.973 & 0.14 & 0.972 & 0.11 & & \\
\hline Body Mass Index & 0.974 & 0.20 & 0.974 & 0.18 & & \\
\hline$\overline{\mathrm{SEL}}$ & 0.815 & 0.27 & 0.796 & 0.21 & & \\
\hline BFAP & 1.000 & 0.99 & 1.104 & 0.80 & & \\
\hline Indigenous & 2.291 & 0.17 & 2.291 & 0.15 & & \\
\hline Cereals $(\mathrm{g} / \mathrm{d})$ & 1.021 & 0.84 & & & 1.124 & 0.2 \\
\hline Meat $(\mathrm{g} / \mathrm{d})$ & 1.085 & 0.56 & & & 1.034 & 0.81 \\
\hline Leguminous (g/d) & 1.473 & 0.10 & & & 1.499 & 0.12 \\
\hline Vegetables (g/d) & 0.786 & 0.46 & & & 0.783 & 0.49 \\
\hline $\begin{array}{l}\text { * Socioeconomic status w } \\
\text { ₹FAP (Beneficiary of fo } \\
\text { subsidized prices, or free } \\
\S \text { Indigenous was a dumm) }\end{array}$ & $\begin{array}{l}\text { ariable by a } \\
\text { grammes, } \mathrm{v} \\
\text { and } 0=\text { no) }\end{array}$ & $\begin{array}{l}\text { uct bas } \\
\text { ummy }\end{array}$ & $\begin{array}{l}\text { oonent analy } \\
0=\text { no) belo }\end{array}$ & $\begin{array}{l}\text { househ } \\
\text { a fam }\end{array}$ & $\begin{array}{l}\text { ions and che } \\
\text { g corn tortil }\end{array}$ & ristics \\
\hline
\end{tabular}

both women and children, the prevalence of subclinical deficiency $(>10.0<20 \mathrm{mg} / \mathrm{dl})$ affected almost onefourth of children $<8$ years of age. Women were not often affected. Considering that even in well-nourished pairs, the serum retinol levels of the newborn are about $50 \%$ lower than the maternal concentrations, this reflects limited body stores of the offspring. ${ }^{31,32}$ Vitamin A depletion in the children who were subjects in ENN-99 might be caused by inadequate dietary intake of the vitamin. Breast milk is the initial source of vitamin A for the newborn to build up adequate body stores, but its vitamin A content is dependent on ma- 
ternal status. ${ }^{33}$ Based on the low prevalence of subclinical deficiency of vitamin A in women of childbearing age, it is unlikely that insufficiency of vitamin A in breast milk content played an important role in the high prevalence of subclinical deficiency of vitamin A of young children in this sample. Among other dietary insufficiencies relative to older children are the low consumption of fruits and vegetables found in the ENN99. In support of this hypothesis, we found that subclinical deficiency of vitamin A was higher in the lower SEL. This suggests that children with lower accessibility to high quality diets (including foods rich in vitamin A: eggs, milk, fruits and vegetables), are at higher risk of being deficient. The inverse association between vitamin A deficiency and age is also suggestive that a more diverse diet is acquired over time, with a denser intake of vitamin A. The lack of association between dietary intakes and vitamin A deficiency might be due to the lack of precision of a single 24-h recall; there is a need for 6 recalls obtaining a precision of $\pm 20 \% .{ }^{34}$ It is noteworthy that the public health programs administered by the Mexican health authorities include the administration of an oral macro dose of vitamin A, twice yearly, to children $<2$ years of age who live in depressed socioeconomic areas. This might contribute to the low prevalence of vitamin A deficiency in small children; however, the effectiveness of such a program has not been evaluated yet. Other nutrition interventions, as is the case of supplements provided by the Programa de Educación Salud y Alimentación (Progresa) to preschoolers living in extreme poverty, has already shown some improvement in their vitamin A status. ${ }^{35}$ Although the prevalence of severe vitamin A deficiency was nonexistent in children, the prevalence of subclinical forms of the deficiency is of some concern from a public health point of view. This is because even subclinical deficiencies of vitamin A are associated with increased morbidity and mortality. ${ }^{2}$ Also, because this vitamin A-depleted population will become deficient in the eventuality of harsh conditions such as natural disasters or economic hardship. The above factors call for a stronger public nutrition intervention with a focus on children $<8$ years of age.

The high prevalence of vitamin $C$ deficiency was unexpected, but consistent with the data on dietary intake collected in ENN-99. Fruits and vegetables ranked very low in the list of foods most frequently eaten: oranges ranked $5^{\text {th }}$, guava $9^{\text {th }}$, broccoli $10^{\text {th }}$ and bananas $11^{\text {th }}$, with an average daily intake $<5 \mathrm{~g}$ for any of those foods. In children, the serum concentration of ascorbic acid was directly associated with the intake of vitamin C, supporting this notion (data not shown). Socioeconomic status was also a determinant of vitamin $\mathrm{C}$ de- ficiency, suggesting that fruits and vegetables are either not affordable by the lowest socioeconomic groups or are not culturally included in their normal diet. In any case, such a high prevalence of vitamin $C$ deficiency is unacceptable because of its important role as a facilitator of iron absorption ${ }^{36}$ as well as in the synthesis of collagen. ${ }^{8}$ In a country where corn is the main staple, iron absorption is extremely depressed by its high content of phytate, resulting in a high prevalence of iron deficiency anemia. A better intake of ascorbic acid in the diet could neutralize the negative effects of phytate. In a recent publication, a positive association between ferritin concentrations and the dietary intake of ascorbic acid after controlling for age was reported in non-pregnant Mexican women aged 16-44 years. ${ }^{37}$ Premature rupture of membranes is frequent in pregnant women who are vitamin $C$ deficient, ${ }^{9}$ resulting in a shorter gestation and low birth weight. Thus, increasing the dietary intake or supplementation with vitamin $C$ for women at risk may help alleviate the problem of premature rupture of membranes and the high prevalence of iron deficiency anemia.

The low prevalence of folate deficiency among women of childbearing age subjects to ENN-99 seems to be in contradiction with the high and growing prevalence of neural tube defects in Mexico. ${ }^{38}$ Such a low prevalence may not reflect the true folate status of these women; the basis for such speculation is the high prevalence of iron deficiency. Iron deficiency may mask folate deficiency. Studies in humans ${ }^{39,40}$ with iron deficiency anemia have shown that the folate content in erythrocytes and other indicators of folate status are normal, and evolve to abnormally low once iron deficiency is corrected. Further, the average daily intake of folic acid found in ENN-99 was $215 \mu \mathrm{g},{ }^{13}$ almost half the recommended intake. In such an assessment the losses due to food preparation were not considered. It is frequent in Mexico that vegetables are intensely boiled or fried before eating them. ${ }^{41}$ In a separate analysis of this database, Pérez-Expósito et al ${ }^{42}$ found that $16 \%$ of the cases of anemia in women of childbearing age were not explained by iron deficiency, most of which were associated with low hemoglobin folate levels. Recently, B12 and serum folate determinations were performed by Dr L. Allen (UC-Davis, CA, unpublished data), in serum samples from ENN-99 and found a prevalence of B12 deficiency in almost $7 \%$ $(<80 \mathrm{pg} / \mathrm{ml})$ and of serum folate of $50 \%(<3 \mathrm{ng} / \mathrm{ml})$ in childbearing-age women. The latter results support the notion that B12 deficiency plays a minor role in the pathogenesis of neural tube defects in Mexico. Secondly, the high prevalence of serum folate deficiency along with normal levels of hemoglobin folate is highly 
suggestive of a hidden folate deficiency, ${ }_{10}^{40}$ possibly associated to the documented high prevalence of iron deficiency (refer to article in this issue on minerals). The method used to collect and preserve the samples for the determination of folate in total blood is novel and very convenient for epidemiological studies under adverse field conditions. Blood is collected in filter paper and conserved at $4^{\circ} \mathrm{C}$, avoiding the meticulous procedures needed to process and preserve blood samples that are routinely used, i.e. dilute the blood sample with metaphosphoric acid and maintain it preserved from light at $-40^{\circ} \mathrm{C}$, which is difficult under most fieldwork conditions. Validation for this procedure has been extensively documented. ${ }^{18-20}$ Further studies are necessary to elucidate whether the correction of iron deficiency reveals folate deficiency. In Mexico public health nutrition programs directed at combating iron deficiency anemia have included adequate amounts of folic acid in their micronutrient formulation, so an epidemic of folate deficiency is unlikely unmasked by the correction of iron deficiency.

In summary, the high prevalence of subclinical deficiency of vitamin A in children and vitamin C deficiency in both children and women of childbearing age in Mexico is of high interest for public nutrition and require programmatic implementations in order to correct them. Such an action may contribute to reducing the rate of acute infections in children and a decrease of low birth weight babies, also resulting in the improvement of the iron status of the general population. It is crucial to elucidate whether the prevalence of folic acid deficiency is spuriously low, masked by the high prevalence of iron deficiency. Further studies such as clinical trials are in order to identify the putatively masked folate deficiency.

\section{References}

1. Svedberg P. Poverty and undernutrition. N ew York: O xford U niversity Press, 2000.

2.W est KP. D ietary vitamin-A deficiency: Effects on growth infection, and mortality. Food N utr Bull 1991;19:119-131.

3. Hadi H, Stoltfus RJ, Moulton LH, Dibley MJ,W est KP. Respiratory infections reduce the growth response to vitamin A supplementation in a randomized controlled trial. Int J Epidemiol 1999;28:874-881 4. Sedgh G, Herrera MG, N estel P, elA min A, Fawzi W W. D ietary vitamin A intake and nondietary factors are associated with reversal stunting in children. J N utr 2000;130:2520-2526.

5. Lindembaum J,Allen RH. C linical spectrum and diagnosis of folate deficiency. In: Folate in health and disease. Bailey LB, Ed. N ew York: Marcel D ekker 1995;43-74.
6. Blomhoff HK, Smeland EB. Role of retinoids in normal hematopoiesis and the immune system. In:Vitamin A in health and disease. Blomhoff $R$, Ed. N ew York: Marcel D ekker,1994:451-484.

7. Daly LE, Kirke PN , Mohillo A,W eir DG, Scott JM. Folate levels and neural tube defects. Implications for prevention. JAMA 1995;274:

1698-1702.

8. C asanueva E, Magaña L, Pfeffer E, Báez A. Incidence of premature rupture of membranes in pregnant women with low leukocyte levels of vitamin C. Eur J C lin N utr 1991;45:401-405.

9. Casanueva E,Avila H, Polo E,Tejero E, N arcia ML, Pfeffer F.Vitamin C status, cervico-vaginal infection and premature rupture of amniotic membranes. Arch Med Res 1995;26:S149-S152.

10. Blumberg JB. Considerations of the scientific substantiation for antioxidant vitamins and beta-carotene in disease prevention. Am J Clin N utr 1995;62:1521-1526.

11. Sepúlveda-A mor J, Lezana MA, Tapia-C onyer, Valdespino JL, Madrigal $H$, Kumate J. Estado nutricional de preescolares y mujeres en México: resultados de una encuesta probabilística nacional. $\mathrm{G}$ ac Med Mex 1990;126:207-224.

12. Segundo Censo $\mathrm{N}$ acional de talla. En niños de primer grado de primaria. Informe técnico ejecutivo. México, D F: Sistema $\mathrm{N}$ acional para el desarrollo integral de la familia, 1996.

13. Rivera J, Shamah T,Villalpando S, G onzález T, Hernández B, Sepúlveda J, ed. Encuesta $\mathrm{N}$ acional de $\mathrm{N}$ utrición 1999. Estado $\mathrm{N}$ utricio de $\mathrm{N}$ iños y Mujeres en México. Cuernavaca, Morelos, México. Instituto $\mathrm{N}$ acional de Salud Pública, 2001.

14. Rivera J, Bourges H,A Arroyo P, C asanueva E, Chávez A, Halhalali A et al. 1. D eficiencia de micronutrimentos. En: De la Fuente JR, Sepúlveda J comp. Diez problemas relevantes de salud pública en México México, DF: Fondo de Cultura Económica,1999:15-57.

15. Rosado JL, Bourges H, Saint-Martin B. D eficiencias de vitaminas y minerales en México. Una revisión crítica del estado de la información. II. D eficiencia de vitaminas, Salud Publica Mex 1995:37:452-461. 16. Sowell AL, H uff D L, Yeager PR, C audill SP, G unther EW. Retinol, tocopherol, lutein, cryptoxanthine, lycopene, carotene and four retinyl-esters in serum, determined simultaneously by reverse-phase HPLC with length detection. Clin Chem 1994;40:411-416.

17. Pilch SM. Assessment of the vitamin A nutritional status of the US population based on data collected in the Health and $\mathrm{N}$ utrition Examination Surveys. Bethesda, (MD): Life Science Research 0 ffice, Federation of American Biological Societies,1985.

18. 0 'Broin SD, G unther EW. Screening of folate status with the use of dried blood spots on filter paper.Am J C lin N utr 1999;70:359-367.

19. O 'Broin SD, Kelleher BP, Davoren A, G unter E. Field-study screening of blood folate concentrations: Specimen stability and finger-stick sampling. Am J C lin N utr 1997;66:1398-1405.

20. O 'Broin SD, Kelleher BP, Gunter E. Evaluation of factor influencing precision in the analysis of samples taken from blood spots on filter paper. Clin Lab Haematol 1995;17:185-188.

21. 0 'Broin SD, Kelleher B. Microbiological assay on microtitre plates of folate in serum and red cells. . C lin Pathol 1992;45:344-347.

22. Wagner $C$. Folic acid. In: Brown M, Ed. Present knowledge in nutrition. $B 5^{\text {th }}$ ed. The N utrition Foundation, Inc (Pub);W ashington, DC, 1984:33.

23. Herman HH, W imalasena K, Fowler LC, N ear CA, May SW. Demonstration of the ascorbate dependence of membrane bound dopamine B-monoxigenase in adrenal chromaphin granule ghosts. J Biol Chem 1988;263:666-672.

24. Sauberlich HE.Ascorbic acid (vitamin C). In: Labbé RF, Ed. Symposium on laboratory assessment of nutritional status. Clin Lab Med 1981;673-684 
25. Morales J, BabinskyV, Bourges H, C amacho ME. Tablas de composición de alimentos mexicanos del Instituto $\mathrm{N}$ acional de Ciencias Médicas y N utrición "Salvador Zubirán". México, DF: IN C MN Salvador Zubirán, 2000.

26. Muñoz M, Chávez A, Pérez-Gil F, Roldán JA, Hernández S, Ledesma JA.Tablas de valor nutritivo de los alimentos de mayor consumo en México. México, DF: Editorial Pax,1996.

27. US D epartment of A griculture, A gricultural Research Service. USDA N utrient D atabase for Standard Reference, Release 13.W ashington, DC: N utrient Data Laboratory, 1999.

28. Food Composition and N utrition Tables. Der zusament setzung der Lebensmittel, $\mathrm{N}$ ährwert - Tabellen/on behalf of the Bundesministerium für Ernährung, Land wirts shaft und Forsten, Bonn, ed. Scherz H, Senser F, Comp. Stuttgart: Medpharm Scientific and CRC Press, London, 2000. 29. Instituto de Nutrición de Centroamérica y Panamá. Tabla de composición de alimentos. G uatemala: IN CAP, 1994.

30.Anonimous. W orld Food Dietary Assessment System.V 2.0. Berkeley: University of California, 1997.

31.Yeum KJ, Ferland G, Patry J, Russell RM. Relationship of plasma carotenoids, retinol and tocopherols in mothers and newborn infants. J Am Coll N utr 1998;17:442-447.

32. Ramalho RA, dos Anjos LA, Flores H. N utritional status of vitamin A in mother/newborn pairs from 2 hospital nurseries in Rio de Janeiro, Brazil. Arch Latinoam N utr 1999;49:318-321.

33. Stoltzfus RJ, Hakimi M, Rasmussen KM, D awiesah S, Habicht JP, Dibley MJ. High-dose vitamin A supplementation for breastfeeding Indonesian mothers: Effects on the vitamin A status of mother and infant. J N utr 1993;123:666-675.

34. Persson V,W inkist A, Hartini N S, G reiner T, Hakimi M, Stenlund H. Variability in nutrient intakes among pregnant women in Indonesia:
Implications for the design of epidemiological studies using the 24-h recall method. J N utr 2001;131:325-330.

35. Rivera JA, Rodríguez G, Shamah T, Rosado JL, C asanueva E et al. Implementation, monitoring, and evaluation of the nutrition component of the Mexican Social Programme (Progresa). Food N utr Bull 2000;21:35-42.

36. Sandstrom B. Micronutrient interactions: Effects on absorption and bioavailability. Br J N utr 2001;85(Suppl 2):S181-S185.

37. Backstrand JR, Allen LH, Black AK, D e Mata M, Pelto GH. D iet and iron status of nonpregnant women in rural Central Mexico. Am J Clin N utr 2002;76:156-164.

38. Leck I. Causation of neural tube defects: Clues from epidemiology. Br Med Bull 1974:30:158-163.

39. D as K, Herbert V, Colman N, Longo D L. Unmasking covert folate deficiency in iron deficient subjects with neutrophil hypersegmentation: UD suppression test on lymphocytes and bone marrow. Br J Haemat 1978;39:357-375.

40. 0 mer A, Finlayson N DC, Shearman DJC, Samson RR, Girdwood RH. Plasma and erythrocite folate in iron deficiency and folate deficiency. Blood 1970;35:821-828.

41.Villalpando S, Latulippe ME, Rosas G, Irurita MJ, Picciano MF,

0 'Connor DL. Low milk folate but not milk iron concentrations may contribute to the observed growth faltering among infants in a rural farming community in San Mateo, Capulhuac, Mexico.Am J C lin N utr 2003. Accepted for publication.

42. Pérez-Expósito AB.Anemia y deficiencia de micronutrimentos en mujeres mexicanas de 12 a 49 años de edad (Tesis de maestría). Madrid, España: Instituto de Salud Pública Carlos III, 2001. 